\title{
Emergency Microsurgery for Aneurysmal Subarachnoid Hemorrhage Coexisting with Brain Hernia
}

\section{Beyin Herniasyonuna Eşlik Eden Anevrizmal Subaraknoid Kanama İçin Acil Mikrocerrabi}

\author{
Tian-Shu LU ${ }^{1,2}$, Jing-Yu GUAN ${ }^{1}$, Chun-Li AN ${ }^{2}$ \\ ${ }^{1}$ Shenyang Northern Hospital, Department of Neurosurgery, Shenyang, China \\ ${ }^{2}$ China Medical University, School of Basic Medicine, Shenyang, China
}

Corresponding Author: Chun-Li AN / E-mail:chunliancn@126.com

\begin{abstract}
AIM: This work aims to summarize the experience in emergency microsurgery for patients with aneurysmal subarachnoid hemorrhage (SAH) that coexisted with brain hernia.

MATERIAL and METHODS: A total of 26 patients with aneurysmal SAH complicated by brain hernia were subjected to emergency aneurysm clamping + decompressive craniectomy. 10 patients were diagnosed with aneurysmal SAH coexisted with brain hernia before operation.

RESULTS: Four patients had a carotid aneurysm, 15 had a middle artery aneurysm, and 7 had an anterior communicating aneurysm. The surgical procedure was performed smoothly for all patients. The patients were followed up for 3 months to 6 months. According to Glasgow outcome scaling, five patients recovered well, six suffered from moderate disability, five were subjected to severe disability, five were in plant survival, and 5 died.
\end{abstract}

CONCLUSION: Emergency surgical exploration is an effective treatment method for patients

KEYWORDS: Aneurysm, Brain hernia, Emergency, Subarachnoid hemorrhage, Surgery

öz

AMAÇ: Çalışma, beyin herniasyonuna eşlik eden anevrizmal subaraknoid kanama (SAK) hastalarında acil mikrocerrahi deneyimini özetlemeyi amaçlamaktadır.

YÖNTEM ve GEREÇLER: Beyin herniasyonu ile komplike anevrizmal SAK'sı olan 26 hastada acil anevrizma klipleme + dekompresif kraniyektomi yapıldı. 10 hastaya ameliyattan önce beyin herniasyonuna eşlik eden anevrizmal SAK tanısı konuldu.

BULGULAR: Dört hastada karotid anevrizma, 15'inde orta serebral arter anevrizması ve 7'sinde anterior komünikan arter anevrizması vardı. Cerrahi müdahale bütün hastalarda sorunsuz uygulandı. Hastalar 3 ila 6 ay boyunca takip edildi. Glasgow sonuç ölçekleme yöntemine göre beş hasta tam iyileşti, altısı orta derecede, beşi ise ciddi maluliyet yaşadı. Beş hasta bitkisel hayata girdi ve beşi ise öldü.

SONUÇ: Acil cerrahi hastalar için etkili bir tedavi yöntemidir.

ANAHTAR SÖZCÜKLER: Anevrizma, Beyin herniasyonu, Acil, Subaraknoid kanama, Cerrahi

\section{INTRODUCTION}

Although the techniques of neuroimaging, microsurgery, and intravascular intervention have advanced significantly in recent years, intracranial aneurysmal subarachnoid hemorrhage (SAH) still has high fatality and disability rates, especially in patients in adverse grade. For this reason, it remains a difficulty in neurosurgery. Aneurysmal SAH coexisted with brain hernia is often accompanied by intracerebral hematoma; when such a condition occurs, patient's condition will turn more serious and higher disability and fatality rates will occur, compared with aneurysmal SAH without intracerebral hematoma (5). Therefore, early diagnosis and accordingly-decided rational treatment greatly influence the prognosis of this condition. However, whether surgery is necessary for low-grade aneurysmal SAH and what is the appropriate timing of surgical treatment remain controversial nowadays. Some scholars prefer conservative therapy, and according to them, surgery can only be performed after patient's condition improves and the grade of SAH decreases, whereas others favor early surgery, which is expected to save as many patients as possible on the premise of without aggravating poor prognosis $(1,3,7,9,23)$. Despite the disagreement, more and more studies have reported that active surgery, as well as careful post-operative intensive care, can increase the survival odds of patients with severe lowgrade aneurysmal SAH $(15,22)$. 
In the current study, emergency microsurgeries for 26 patients suffering from aneurysmal SAH coexisted with brain hernia were analyzed retrospectively.

\section{MATERIAL and METHODS}

\section{General Data}

A total of 26 patients, including 10 males and 16 females, were enrolled in this study. Their ages ranged from 22 years to 66 years with a mean age of $43.55 \pm 13.20$ years. Among the patients, 16 had had brain hernia before their emergent hospitalization, and 10 presented brain hernia when rehaemorrhagia occurred during their hospital stay. Cranial computed tomography (CT) showed SAH in all patients, frontal lobe hematoma in 6 patients, and temporal lobe and lateral cleft hematoma in 15. According to Hunt grading, 16 patients had grade IV and 10 had grade V. Computed tomographic arteriography was performed for 3 patients and digital subtraction angiography (DSA) for 7, whereas 16 did not receive contrast examination. 4 patients had carotid aneurysm, 15 had middle artery aneurysm, and 7 had anterior communicating aneurysm. This study was conducted in accordance with the declaration of Helsinki. This study was conducted with approval from the Ethics Committee of China Medical University. Written informed consent was obtained from all participants.

\section{Surgical Methods}

An extended pterion approach was adopted for all patients. The dura mater was cut open. For patients with hematoma, the hematoma was removed first. For those without hematoma, the cornu temporale ventriculi lateralis was dissociated and opened to sufficiently reduce the pressure, and then the lateral cleft was isolated. For patients diagnosed clearly before operation, routine aneurysmal isolation, exposure, and clamping were done. For those who did not receive contrast examination, the pre-operative cranial CT images were analyzed carefully: Aneurysms are often located near arteries in patients with hematoma (e.g. patients with temporal lobe and lateral cleft hematoma often suffer from middle artery aneurysm, and those with frontal lobe and cerebral ventricle hematoma often have carotid or anterior communicating aneurysm); for patients without noticeable hematoma, carotid, posterior communicating, anterior, anterior communicating, and middle arteries as well as their branches were carefully observed in sequence. Decompressive craniectomy was performed at the end of operation, and the dura mater was sutured using the relaxation method. After operation, all patients were subjected to lumbar punctures to release bloody cerebrospinal fluid until it was tested normal.

\section{RESULTS}

\section{Post-Operative Outcomes}

Aneurysmal clamping and decompressive craniectomy were performed smoothly for all patients. The patients were followed up for 3 months to 6 months. According to Glasgow outcome scaling, five patients recovered well, six suffered from moderate disability, five sustained severe disabilities, five were in plant survival, and 5 died.

\section{Typical Case}

Pre- and post-operative $C T$ images of a typical case are shown in Figure 1(A,B) respectively.
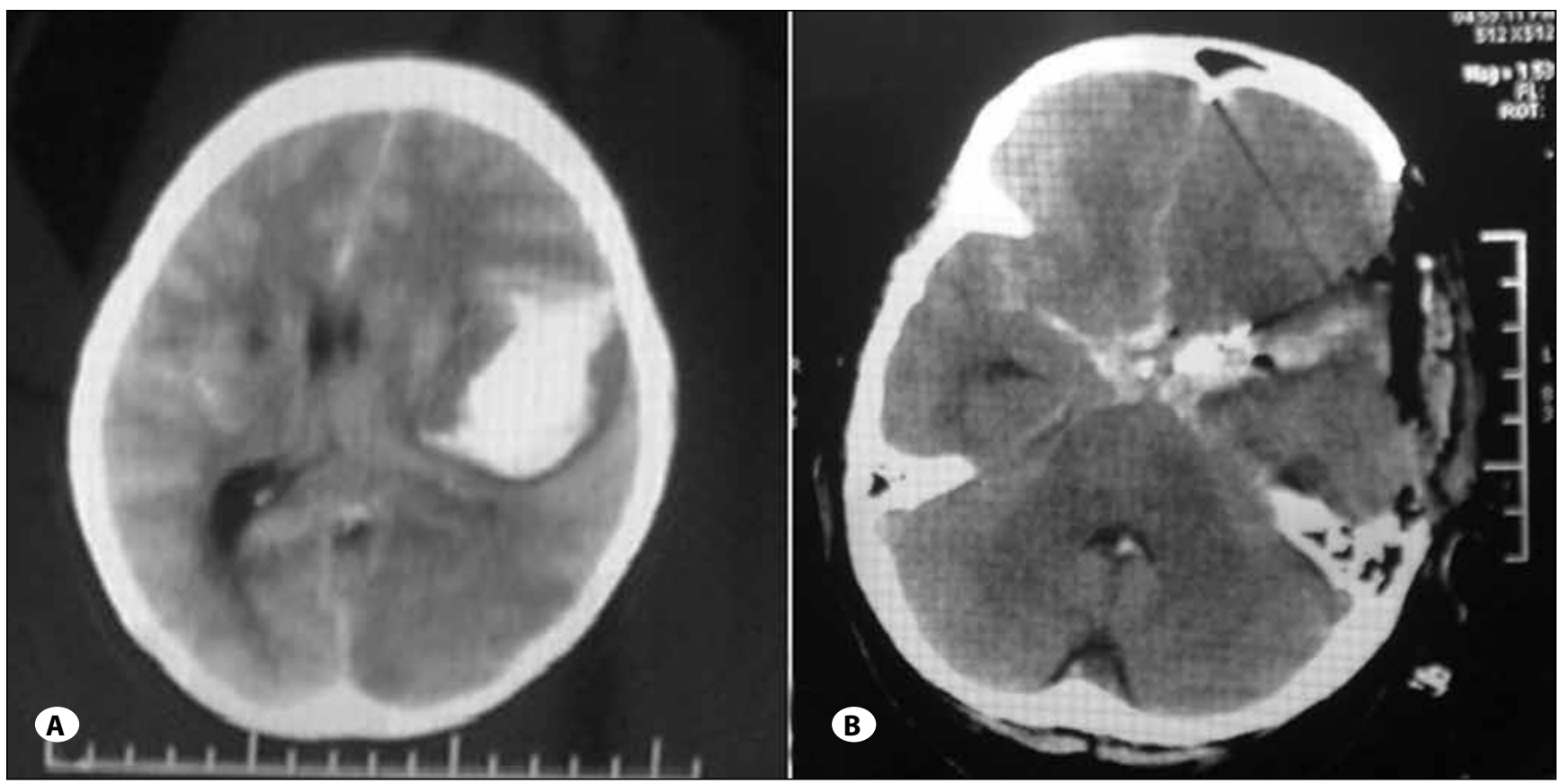

Figure 1: A) CT image before craniotomy for exploration B) CT image of craniotomy for exploration after middle aneurysm clamping + decompressive craniectomy. 


\section{DISCUSSION}

Intracranial aneurysmal rupture leads to an incidence of intracranial hematoma between $4 \%$ and 34\%; patients with intracranial hematoma have a mortality rate between $21 \%$ and $58 \%(4,8,13,18,19)$, which is significantly higher than that of the patients without such a condition (between $6 \%$ and $10 \%)(11,12)$. The results in the present study indicate that emergency operation can effectively avoid or relieve intracranial rehaemorrhagia, cerebral vasospasm, and intracranial pressure increase in patients with aneurysmal rupture complicated by intracerebral hematoma; meanwhile, decompressive craniectomy can further reduce the risk of rehaemorrhagia, which improves treatment effectiveness and decreases mortality.

For operative approach, the extended pterion approach can be adopted as a conventional method. This approach has the following merits: It allows the exploration of anterior circulation aneurysm as well as of middle artery aneurysm; it allows the performance of bone flap decompression as well as of temporal lobe decompression.

However, there are two major challenges faced in emergency surgery for aneurysm complicated by intracerebral hematoma: One is the difficulties in exposing and isolating aneurysm due to high brain pressure, and the other is intraoperative re-rupture and -hemorrhage. To avoid the risks imposed by these challenges, this study observed the principles as follows: DSA and CT images are carefully observed to make judgment of the configuration of aneurysm and associated vessels as well as their correlation with hematoma; controlled hypotension is not adopted to prevent and control rupture and hemorrhage during operation in case of an aggravated cerebral ischemic injury; brain pressure is appropriately decreased before dura mater opening; hematoma around the aneurysm is appropriately removed and the cistern is sufficiently opened to further reduce the pressure, and for those patients in whom satisfactory decompressive effect is not achieved, temporal and frontal poles may be resected; aneurysmal isolation is performed according to the order of the proximal and distal ends of the aneurysm-carrying artery and then the neck of the aneurysm; for patients with multiple aneurysms, the aneurysms close to the Willis cycle are removed first; the aneurysm-carrying vessel is timely blocked during operation, especially for patients whose aneurysm is hard to find in hematoma or with large aneurysm; hematoma is completely removed after aneurysm clamping; and for patients with unsatisfactorily decreased brain pressure at the end of operation, internal and external decompression is performed.

Once aneurysmal rupture occurs before aneurysm detachment, the ipsilateral carotid artery should be compressed immediately to reduce hemorrhage, and hyperventilation is performed to decrease intracranial pressure; meanwhile, a brain spatula was inserted from the skull base to absorb the hemorrhage (for patients difficult to treat, part of brain lobes can be absorbed). When the operation arrived at the proximal part of the aneurysm-carrying artery, temporary obstruction of the artery is performed, and then the aneurysm is dealt with quickly. If aneurysmal rupture occurs during the time of aneurysm isolating, the aneurysm-carrying artery should be temporarily blocked (or even the aneurysm is left isolated), and then conventional handling procedure is performed. For patients with a tumor body or top rupture, if the rupture is small, hemostasis can be done by cauterizing the rupture using weak bipolar electrocautery; however, if the rupture is large, it should be clamped by using an artery clamp (or the rupture and part of the tumor body are clamped together). Then, the isolation of the tumor neck is continued and a tumor clamp is afterwards applied. Ruptures can also occur at the time of clamping. Most of these ruptures belong to neck ruptures and tears. For the former, the aneurysm-carrying artery is blocked temporarily, the tumor detachment is furthered, the tumor clamp is moved deeply in the direction of the aneurysm-carrying artery, and then the artery is clamped. For the latter, permanent occlusion of the aneurysm-carrying artery has to be done in most cases due to a difficulty in hemostasis, which often leads to serious consequences. Based on clinical practices, the experience of the authors of this study is that for aneurysm with a wide and thin neck, the aneurysm-carrying artery should be obstructed temporarily first, and a tumor clamp is placed after the tension of the neck is reduced; meanwhile, the clamp should be placed as close to the aneurysm-carrying artery as possible.

Post-operative intracranial hypertension is an important prognosis-related factor (10). All brain damages directly caused by intracranial hematoma, cerebrospinal fluid circulation disorder, cerebral vasospasm, and aneurysm can lead to a rapid increase in intracranial pressure. Therefore, if intracranial hematoma, blood clots around the associated artery, and hematocele in the cistern are cleaned as soon as possible shortly after aneurysmal rupture, cerebral vasospasm can be eased. Additionally, continuous external ventricular drainage and bone flap removal are performed, which can reduce intracranial pressure to improve cerebral circulation. These treatments can reduce secondary cerebral damages caused by intracranial hypertension to the minimum. Thus, emergency surgery to remove intracranial hematoma and bone flaps serves as an important procedure for reducing intracranial pressure and relieving secondary brain damages.

Furthermore, cerebral vasospasm is another serious complication which influences the prognosis of intracranial aneurysm accompanied by intracerebral hematoma $(2,6,16$, $17,20,21)$. It often results in abrupt deterioration of patient's condition or even patient's death during disease course. The occurrence of cerebral vasospasm is closely correlated with factors such as hematocele in the cistern and aneurysmal rupture. Not only can emergency surgery remove intracranial hemotocele and occlude aneurysm to eliminate part of the factors causing cerebral vasospasm, but it can also be performed before the occurrence of cerebral vasospasm to avoid the risk of pathogenetic condition aggravation during the period of cerebral vasospasm. In addition, combined 
lumbar puncture can weaken the stimulation of $\mathrm{SAH}$, which greatly reduces the probability of vasospasm (14).

To sum up, patients with aneurysmal SAH coexisted with brain hernia should receive surgical treatment actively. For patients suspected with such a condition, CT images should be carefully analyzed and surgical exploration is then done. Decompressive craniectomy can reduce intracranial pressure and improve cerebral perfusion to improve the prognosis of the disease.

\section{REFERENCES}

1. Bailes JE, Spetzler RF, Hadley MN, Baldwin HZ: Management morbidity and mortality of poor grade aneurysm patients. J Neurosurg 72: 559-566, 1990

2. Carvi y Nievas $M$, Toktamis $S$, Höllerhage HG, Haas E: Hyperacute measurement of brain-tissue oxygen, carbon dioxide, $\mathrm{pH}$, and intracranial pressure before, during, and after cerebral angiography in patients with aneurysmatic subarachnoid hemorrhage in poor condition. Surg Neurol 64: 362-367, 2005

3. Gupta SK, Ghanta RK, Chhabra R, Mohindra S, Mathuriya SN, Mukherjee KK, Umredkar AU, Singla N: Poor-grade subarachnoid hemorrhage: Is surgical clipping worthwhile? Neurol India 59: 212-217, 2011

4. Güresir E, Beck J, Vatter H, Setzer M, Gerlach R, Seifert V, Raabe A: Subarachnoid hemorrhage and intracerebral hematoma: Incidence, prognostic factors, and outcome. Neurosurgery 63: 1088-1093, 2008

5. Hauerberg J, Eskesen V, Rosenorn J: The prognostic significance of intracerebral hematoma as shown on CT scanning after aneurysmal subarachnoid haemorrhage. $\mathrm{Br} \mathrm{J}$ Neurosurg 8: 333-339, 1994

6. Huang AP, Arora S, Wintermark M, Ko N, Tu YK, Lawton MT: Perfusion computed tomographic imaging and surgical selection with patients after poor-grade aneurysmal subarachnoid hemorrhage. Neurosurgery 67: 964-974, 2010

7. Kassell NF, Torner JC, Jane JA, Haley EC Jr, Adams HP: The international cooperative study on the timing of aneurysm surgery. J Neurosurg 73: 37-47, 1990

8. Komotar RJ, Schmidt JM, Starke RM, Claassen J, Wartenberg KE, Lee K, Badjatia N, Connolly ES Jr, Mayer SA: Resuscitation and critical care of poor-grade subarachnoid hemorrhage. Neurosurgery 64: 397-410, 2009

9. Lai JD, Siu KH: Poor grade aneurysmal subarachnoid hemorrhage: Outcome after treatment with urgent surgery. Neurosurgery 53: 1275-1282, 2003

10. Le Roux PD, Elliott JP, Newell DW, Grady MS, Winn HR: Predicting outcome in poor-grade patients with subarachnoid hemorrhage: A prospective review of 159 aggressively managed cases. J Neurosurg 85: 39-49, 1996

11. Mocco J, Ransom ER, Komotar RJ, Schmidt JM, Sciacca RR, Mayer SA, Connolly ES Jr: Preoperative prediction of longterm outcome in poor-grade aneurysmal subarachnoid hemorrhage. Neurosurgery 59: 529-538, 2006
12. Otani N, Takasato $\mathrm{Y}$, Masaoka $H$, Hayakawa T, Yoshino $\mathrm{Y}$, Yatsushige $\mathrm{H}$, Miyawaki $\mathrm{H}$, Sumiyoshi K, Chikashi A, Takeuchi S, Suzuki G: Surgical outcome following decompressive craniectomy for poor-grade aneurysmal subarachnoid hemorrhage in patients with associated massive intracerebral or Sylvian hematomas. Cerebrovasc Dis 26: 612-617, 2008

13. Pereira AR, Sanchez-Peña P, Biondi A, Sourour N, Boch AL, Colonne C, Lejean L, Abdennour L, Puybasset L: Predictors of 1-year outcome after coiling for poor-grade subarachnoid aneurysmal hemorrhage. Neurocrit Care 7: 18-26, 2007

14. Ransom ER, Mocco J, Komotar RJ, Sahni D, Chang J, Hahn DK, Kim GH, Schmidt JM, Sciacca RR, Mayer SA, Connolly ES: External ventricular drainage response in poor grade aneurysmal subarachnoid hemorrhage: Effect on preoperative grading and prognosis. Neurocrit Care 6: 174-180, 2007

15. Sasaki T, Sato M, Oinuma M, Sakuma J, Suzuki K, Matsumoto M, Kodama N: Management of poor-grade patients with aneurysmal subarachnoid hemorrhage in the acute stage: Importance of close monitoring for neurological grade changes. Surg Neurol 62: 531-535, 2004

16. Schmidt JM, Wartenberg KE, Fernandez A, Claassen J, Rincon F, Ostapkovich ND, Badjatia N, Parra A, Connolly ES, Mayer SA: Frequency and clinical impact of asymptomatic cerebral infarction due to vasospasm after subarachnoid hemorrhage. J Neurosurg 109: 1052-1059, 2008

17. Seule MA, Muroi C, Mink S, Yonekawa Y, Keller E: Therapeutic hypothermia in patients with aneurysmal subarachnoid hemorrhage, refractory intracranial hypertension, or cerebral vasospasm. Neurosurgery 64: 86-92, 2009

18. Shirao S, Yoneda H, Kunitsugu I, Ishihara H, Koizumi H, Suehiro E, Nomura S, Kato S, Fujisawa H, Suzuki M: Preoperative prediction of outcome in 283 poor-grade patients with subarachnoid hemorrhage: A project of the Chugoku-Shikoku Division of the Japan Neurosurgical Society. Cerebrovasc Dis 30: 105-113, 2010

19. Taylor CJ, Robertson F, Brealey D, O'shea F, Stephen T, Brew S, Grieve JP, Smith M, Appleby I: Outcome in poor grade subarachnoid hemorrhage patients treated with acute endovascular coiling of aneurysms and aggressive intensive care. Neurocrit Care 14: 341-347, 2011

20. Tseng MY, Al-Rawi PG, Czosnyka M, Hutchinson PJ, Richards H, Pickard JD, Kirkpatrick PJ: Enhancement of cerebral blood flow using systemic hypertonic saline therapy improves outcome in patients with poor-grade spontaneous subarachnoid hemorrhage. J Neurosurg 107: 274-282, 2007

21. Wartenberg KE: Critical care of poor-grade subarachnoid hemorrhage. Curr Opin Crit Care 17: 85-93, 2011

22. Wartenberg KE, Sheth SJ, Michael Schmidt J, Frontera JA, Rincon F, Ostapkovich N, Fernandez L, Badjatia N, Sander Connolly E, Khandji A, Mayer SA: Acute ischemic injury on diffusion-weighted magnetic resonance imaging after poorgrade subarachnoid hemorrhage. Neurocrit Care 14:407-415, 2011

23. Wong GK, Boet R, Ng SC, Chan M, Gin T, Zee B, Poon WS: Ultra-early (within 24 hours) aneurysm treatment after subarachnoid hemorrhage. World Neurosurg 77:311-315, 2012 